\title{
4. Hearing Aboriginal Music Making in Non-Indigenous Accounts of the Bush from the Mid-Twentieth Century
}

\author{
Amanda Harris
}

Mid-century non-Indigenous travellers in the Australian bush found themselves confronted with a new auditory world, one in which the sounds of the city were absent, and the sounds of the bush unfamiliar. The reckonings of these travellers with aural encounters of people, place and animals often came to stand for a complex set of reactions to being in the bush. The way they listened to Aboriginal music being sung and played around them crystallised perceptions held about Aboriginal people and how they might be located in the Australian landscape. How non-Indigenous authors heard and performed culturally familiar music also reflected ways that they viewed themselves and was a means of bringing the familiar to alien surroundings. In this chapter, I combine accounts from diaries of the 1948 American-Australian Scientific Expedition to Arnhem Land with depictions from novels written within two decades of the expedition to give examples of the way Aboriginal music was heard by non-Indigenous travellers. In the process I tease out some of the perceptions of a range of commentators on Aboriginal culture that are revealed in these musical encounters. I also consider how this sound world was brought to bear on a musical composition by Peter Sculthorpe from a slightly later period and reflect on how the musical setting of Aboriginal song themes reveals similar preoccupations to these literary descriptions.

Phyllis Weliver's analysis of the nineteenth century novel The Moonstone depicts music trumpeting the first British encounters with visitors from India: 'the sound of the Indian drum penetrates the walls of an English country home, announcing the presence of the exotic East to its well-heeled inhabitants ... music is heard before the Eastern visitors are seen. ${ }^{1}$ As suggested by this excerpt, Weliver's discussion of Orientalism in British fiction takes as its starting point the auditory space of cross-cultural encounters, in their written manifestations in literature. Weliver's work on aural experiences of the exotic can be seen in the context of recent contributions to historical studies, which have sought not only

\footnotetext{
1 Phyllis Weliver, 'Tom-Toms, Dream-Fugues and Poppy Juice: East meets west in nineteenth-century fiction', in Music and Orientalism in the British Empire, 1780s-1940s, eds Martin Clayton and Bennett Zon (Aldershot: Ashgate, 2007), 257. Other studies that have taken up this subject matter include Ian Woodfield, English Musicians in the Age of Exploration (Stuyvesant: Pendragon Press, 1995), although Woodfield's book focuses on the role of European musicians in the colonisation and exploration process, rather than the reactions of those musicians to Indigenous musics.
} 
to draw on visual accounts - photographs, artefacts and written descriptions of these-but have also been attentive to auditory historical sources. This relatively new approach responds to history writing in which, as Diane Collins wrote in 2006, '[h]istorians disappoint as listeners'. ${ }^{2}$ As one of these new contributors to history drawing on what is heard instead of only what is seen, Martin Thomas has documented the range of recent historical writings which are preoccupied with auditory experience, including the 2004 volume, Hearing History: A reader. ${ }^{3}$ There is also a growing body of work which seeks to enliven the historical sound world of Australia from pre-colonial to postcolonial times. In this chapter, I contribute a fragment to this greater reconstruction of heard cultures. In describing the sound world of non-Indigenous travellers, I draw on R. Murray Schafer's definition of a 'soundscape' as the 'acoustic environment' of, in this case, the Australian bush as inhabited by both Aboriginal people and more recent arrivals. ${ }^{4}$

I begin with the diaries of a group of American and Australian scientists and support staff who, in 1948, set out on a nine-month journey to east, central and west Arnhem Land in the north of Australia. In the three main camps they established, in Umbakumba on Groote Eylandt, in Yirrkala, and Oenpelli (now Gunbalanya), the travellers focused their attention on different acts of collection: they gathered artworks, archaeological objects, animal and plant specimens, human blood samples and made recordings of music and dance performances. They even stole human bones from burial sites in the vicinity of their camps (some of which have recently been repatriated). ${ }^{5}$ In large part, the expeditioners' approach to their surroundings was that of foreign observers to an alien culture. They built only short-term working relationships with the Aboriginal people they encountered, took notes on the phenomena they observed, and used the proceeds of their work to publish four large volumes of Records of their expedition in the decade following the trip. Although some of the travellers had visited Aboriginal communities in the past, and some had a working knowledge and acquaintance with Indigenous art forms, such as cave and bark paintings and the construction of tools and implements for daily tasks, for many of the participants (and not just those from the far away US),

\footnotetext{
2 Diane Collins, 'Acoustic Journeys: Exploration and the search for an aural history of Australia', Australian Historical Studies 37:128 (2006): 1.

3 Martin Thomas, 'The Rush to Record: Transmitting the sound of Aboriginal culture', Journal of Australian Studies 31:90 (2007): 107-202; Mark M. Smith, ed., Hearing History: A reader (Athens: University of Georgia Press, 2004); See also Joy Damousi and Desley Deacon, eds., Talking and Listening in the Age of Modernity: Essays on the history of sound (Canberra: ANU E Press, 2007).

4 R. Murray Schafer, 'Soundscapes and Earwitnesses,' in Hearing History: A reader, ed. Mark M. Smith (Athens: University of Georgia Press, 2004), 6. Schafer's term originates in R. Murray Schafer, The Tuning of the World (New York: Knopf, 1977), and has since been employed by other authors working on aural histories. See John M. Picker, Victorian Soundscapes (New York: Oxford University Press, 2003); Collins, 'Acoustic Journeys'.

5 See Thomas, this volume.
} 
these were their first encounters with the Indigenous people of Australia in general and the people of different parts of Arnhem Land in particular. One of the ways in which the foreign cultures of the communities of Umbakumba, Yirrkala and Oenpelli were perceived was through auditory experiences of the sounds made by people and the places in which they found themselves. Some of these experiences were recorded in the extensive field diaries that several of the expedition members kept. The auditory experiences recorded fell into three categories: hearing Aboriginal music drifting from nearby camps after dark; on rare occasions, gramophone music or shortwave radio bringing familiar culture from afar; and camp songs that were a spontaneous feature of many an evening's entertainment in the bush.

Novels by authors acquainted with the music of Aboriginal people and those whose knowledge of Indigenous Australians was the result of archival research presented a portrait of Aboriginality that was available for popular consumption. Novels were a medium with a more direct accessibility for the wider Australian public than the research work of ethnologists, whose publications had a narrow and more restricted readership. Where expeditioners' diaries reveal the responses of new travellers to their encounters in the bush, popular novels are indicative of conceptions of Aboriginal people that were placed in circulation in the wider Australian cultural sphere. The novels discussed in this chapter include Katharine Susannah Prichard's Coonardo, Mary Durack's Keep Him My Country, Xavier Herbert's Capricornia, Eleanor Dark's The Timeless Land, and Ion L. Idriess' Drums of Mer. In order to think more fully about the way music is heard, and in drawing not just on written but auditory sources, I also discuss as a point of comparison, the composer Peter Sculthorpe's Port Essington- the first complete work in which he used an Aboriginal melody as his chief melodic material to depict how European colonisers heard their surroundings, and a work held by musicologists as significant in the turn to an Australian compositional style. Before turning to these dramatised accounts of cross-cultural auditory encounters, I begin with the field diaries from 1948.

\section{The Diaries}

Several participants in the 1948 American-Australian Scientific Expedition to Arnhem Land kept avidly-written accounts of their experiences in the locations visited by the expedition in the Top End of Australia. These diary accounts take a number of different forms ranging from the scientific field diaries of nutritionist Margaret McArthur to the personal journal of the expedition's cook and logistics officer, John Bray, which contains a record of his feelings of marginalisation as well as amusing commentary on the habits of the expedition 
scientists. ${ }^{6}$ The diaries alternately document their authors' feelings of alienation from their surroundings and excitement at their encounters with new places, people and cultures. Although music is not a dominant theme in any of the diaries in particular, the participants' responses to music and their auditory world provide an interesting lens for their perceptions of strangeness and connections with home. The diaries of four participants in particular-John Bray, Bob Miller, Bessie Mountford, and Fred McCarthy-discuss music with some frequency, and the ways in which they were able to hear the music around them tells us much about their feelings of cross-cultural negotiation during the course of the nine-month expedition.

In expedition cook and logistics manager John Bray's diary, it is possible to observe a movement from alienation to understanding of the foreign cultures with which he interacted in the time he spent in Arnhem Land. In the early days of the expedition, Bray heard the sounds of Aboriginal music not only as foreign and unfamiliar, but also as incomprehensible and monotonous. Of the didjeridu playing that he heard on 19 April, Bray wrote: 'the range of notes is strictly limited and generally is just like a dull booming sound', ${ }^{7}$ and on 23 April: 'The corroboree goes on every night. Just a repetition of the first $\operatorname{lot}^{\prime}{ }^{8}$ His measured and unenthusiastic tone in these two descriptions can be contrasted with his experience of listening to the short-wave radio on 4 May. In this description, Bray's experience of the 'soft' and 'glorious music' of Eileen Joyce's piano playing was heightened by the strangeness of his surroundings, 'sitting on the sand in Peter's tent, slapping at mosquitos', and was placed by Bray in stark contrast to the 'Wahs' and 'Hoos' of 'the Nightly Corroboree down at the beach', a description that may relate in particular to the overblown hoots of didjeridu style from north-east Arnhem Land. ${ }^{9}$ These early descriptions of how Aboriginal music was heard by Bray correspond with his period of acclimatisation to the new cultural surrounds of Arnhem Land and his attempts to understand the foreign culture of north-east Arnhem Land with which he had only just begun to interact.

Bray's ability to hear subtlety and nuance in the music around him changed in parallel with his growing understanding of the Aboriginal people with whom he worked and studied. His interaction with Aboriginal people continued to be superficial, based mostly around working relationships with assistants employed to help him with the distribution of rations and cooking, until October 1948. In

6 See my discussion of John Bray's, Fred McCarthy's, Margaret McArthur's and Bessie Mountford's diary accounts in Amanda Harris, 'Food, Feeding and Consumption (or the Cook, the Wife and the Nutritionist): The politics of gender and class in a 1948 Australian expedition', History and Anthropology 24:3 (2013): 1-17.

7 John Bray, 'Arnhem Land Expedition 1948', Private Journal, collection of Andrew Bray, 19 April 1948.

8 ibid., 23 April 1948.

9 ibid., 4 May 1948. I am grateful to Linda Barwick for her insight into the characteristic didjeridu sounds of north-east Arnhem Land style. 
that month, he was allocated to a research trip run by the nutritionist, Margaret McArthur, heading out from Oenpelli and camping at a site about twenty kilometres outside of the mission camp for a period of two weeks. Bray travelled with two Aboriginal men, Joshua and Parr-poor-wa (known as Ankor), from the settlement for several days in preparation for the trip, attempting to find a group of people living off the land and wholly independent of rations from the mission. After these days of exploring the surrounding countryside and the two weeks at the designated field site, Fish Creek, or Kunnanj, Bray had developed a more thorough understanding of cultural practice and the lifestyle and habits of the Aboriginal people with whom he was camping, and through this, had come to a deeper relationship with Aboriginal culture. On 30 September he recorded with great interest his experience of encountering a group of people, who were unknown to him and his companions, in the bush and detailed the process they followed of making themselves noticeable to the new group and only slowly approaching them by means of tobacco thrown towards them and shouts to make obvious their presence. ${ }^{10}$

Just as Bray's understanding of cultural practice grew at this time, a shift in his ability to 'hear' Aboriginal music was also evident. Bray's diarised account of the music he heard in this period contrasts significantly with those of April and May of the same year: 'Sat around \& listened to the nightly song \& dance. They have charming songs with varying rhythms \& time \& some we heard tonight would make a splendid recording. ${ }^{11}$ Of course, the music he was hearing here, outside of Oenpelli, was rather different in style from the north-east Arnhem Land music he had heard months before. However, Bray's descriptions show not just a preference for this music from a different region, but a higher level of attention to what was going on musically. It suggests that hearing the same kind of detail that he heard in culturally-familiar music was only possible as his understanding of Aboriginal culture developed. This echoes ethnomusicologist John Blacking's assertion that 'perception of sonic order, whether it be innate or learned, or both, must be in the mind before it emerges as music' ${ }^{12}$ Bray needed to learn order in Aboriginal culture before his mind was able to perceive the order in the music that emerged from that culture.

The American ichthyologist, Bob Miller's approach to describing in his diary the Aboriginal music heard was more analytical and descriptive than those accounts of his fellow Australian expeditioners. It was perhaps Miller's distance from preconceptions of Aboriginal culture, and the novelty of the sounds, which meant that, from his first encounters with it, he was able to describe in detail the shape, timbre and playing of the didjeridu, the rhythmic variation

10 ibid., 30 September 1948.

11 ibid., 18 October 1948.

12 John Blacking, How Musical Is Man? (Seattle: University of Washington Press, 1973), 11. 
of the songs heard and the ceremonial context for the music. While Miller also commented on the pleasant evenings by the gramophone in the house of Fred and Marjorie Gray, the group's hosts at Umbakumba on Groote Eylandt, it was not to contrast the familiarity of this music with the foreignness of Aboriginal singing as Bray did. Rather, while the gramophone music was barely described, Miller heard the Aboriginal music of staged corroborees with a keen ear: 'The throbbing rhythms were fascinating + the chanting monotonous but haunting in its repetition. ${ }^{13}$ Miller's ability to appreciate the music he heard as fascinating hints at the fact that he had fewer preconceptions of what was to be heard in Australian Indigenous music.

Other diarists' accounts of Aboriginal music show that they sought to understand its greater social and cultural significance, instead of judging it purely on aesthetic grounds. Some excerpts from Bessie Mountford's diary highlight this approach. From Mountford's discussions with Fred, one of the Bininj men (western Arnhem Land man) resident at Oenpelli and related to some of those she had met at Yirrkala, she learnt that the ongoing performance of corroborees was intimately related to the wellbeing of Aboriginal groups in a particular area, and even with their ongoing empowerment and independence. In response to Mountford's comment that the native residents at Yirrkala were 'pleasant and happy', Fred agreed: "'Yirrkala bin methodis Mission plenty laugh, plenty sing, plenty corroborree". "Oenpelli" he continued, "C.M. Mission no corroborree, people just sullen."' Bessie Mountford agreed, remarking: 'We certainly notice the difference, but one would need greater experience with both sections to say Yes or No to his simple statement. ${ }^{14}$

In reflecting on this conversation, Mountford touched on an important tenet of Aboriginal cultures across different parts of Australia. As she sought to understand the link between contentment and wellbeing in a particular place, and the practice of singing and dancing or 'corroboree', Mountford grappled with an aspect of culture that non-Indigenous Australians have sought to understand for many years. In her limited contact with Aboriginal people, she had already learned that wellbeing in a particular place was closely linked to the practice of performance traditions linked to that place. Peter Toner's exploration of the link between song and Country confirms the ideas that Mountford was only beginning to understand, not only that songs were intricately linked with particular places, but that singing was intrinsic to the knowledge of Country in its physical, spiritual and historical senses:

13 Bob Miller, 'Diary', Papers of Robert Rush Miller, 1947-51, MS 10053, National Library of Australia (NLA), Canberra, 28 March 1948.

14 Bessie Mountford, 'Diary', Mountford, Bessie Ilma, 1890-1996, PRG487, State Library of South Australia (SLSA), Adelaide, 30 October 1948. 
[P]laces are not only physical landscapes but also countries of the mind. The contemporary socio-historical context is such that songs are not only the expression of pre-existing knowledge about country; it is through songs that many people come to know country in the first place ... for those fortunate enough to live on their country, knowledge of songs is a pre-eminent means of learning about the most esoteric aspects of the spiritual connection between places, people, and ancestral beings and events. ${ }^{15}$

As Toner writes, 'the term songline has been widely adopted as a kind of catchall concept ... which attempts to condense the complexity of Aboriginality into an easy-to-digest form' ${ }^{16}$ Mountford's realisation pointed to her growing understanding that a continuous link to the songs of a particular place was one indicator of cultural continuation and the wellbeing of people on Country in Aboriginal Australia.

Margaret McArthur, the expedition's nutritionist, developed a similar understanding of her heard environment when she spent weeks at a time walking in pursuit of food with local women and camping with groups of Aboriginal people gathering food from the landscape. In response to $\mathrm{ABC}$ journalist Colin Simpson's questions about 'the allegedly slave-like status of native women', McArthur commented that it was:

A lot of nonsense. They live their own lives within the tribe ... have their own secret lodges where they sing and dance their own secret rituals ... go out with them as I did. Listen to them joking and laughing and gossiping as they dig for yams or dive in the lagoon for lily roots. At night watch them dancing, away from the men, their own corroborees, swaying and clapping to the rhythm out there in the fire-glint and the shadows or under the moon. They look, and I think they feel, as little like slaves as I do. ${ }^{17}$

In other words, a chief indicator of the women's wellbeing in McArthur's eyes was women's singing and dancing. Implicit in her refutation of Simpson's claim that Aboriginal women were 'slave-like' was an understanding that to perform corroborees, to maintain one's own musical and dance traditions was to be free or empowered.

It is not difficult to imagine that this understanding of wellbeing associated with music-making was extrapolated from the expedition members' own experiences

15 Peter Toner, 'Sing a Country of the Mind: The articulation of place in Dhalwangu Song', in The Soundscapes of Australia: Music, place and spirituality, ed. Fiona Richards (Aldershot: Ashgate, 2007), 183.

16 Toner, 'Sing a Country of the Mind', 165.

17 Colin Simpson, Adam in Ochre: Inside Aboriginal Australia (Sydney: Angus \& Robertson, 1951), 53. 
in their leisure time over the months of the journey; that this, like many of their observations, was a projection of their own culture onto a foreign one. Fred McCarthy's diaries make perhaps the most commentary on the entertainment provided to the group by the 'singsong' which was a feature of many nights around the camp. In McCarthy's account, members of the group were praised not only for their official expedition role, but also for their ability to contribute songs to the nightly singalong. ${ }^{18}$ McCarthy's observations were part of a larger tradition of song-making in the remote Australian bush, as indicated by Bill Harney's account. Harney, a long-term Northern Territory resident, who spent much of his life in the bush, assisted as guide to the expedition, and came to be regarded as an expert communicator with Aboriginal people, also recounted the nightly song and poetry exchange as a crucial feature of life droving cattle and generally camping in the bush, both as a means of entertainment among the campers and a way of calming the dozing cattle. ${ }^{19}$

\section{The Novels}

Whether as part of direct first-person observations of the sounds of Aboriginal culture and the bush, or as depictions in literature, the projection of one's own culture onto a foreign one is a recurring theme of mid-twentieth century accounts. In her novel The Timeless Land, Eleanor Dark used song-making as a device to indicate the rebelliousness of particular female Aboriginal characters. In Dark's portrayal of a Gadigal woman at the time of British settlement, Bennilong's younger sister, Warreweer, was depicted as transgressing the bounds of cultural expectations of women through the composition of songs:

[T]hough well past the age when most women found husbands and produced children, [Warreweer] not only remained virgin, but shamelessly and persistently produced songs and tales instead. It was true that her fault was not so glaring as Carangarang's had been, for her songs were not such as a man might make, and her tales were not of battles or feats of strength, or of any matters which were more fittingly immortalised by a man; but there was an element in them, all the same, which some of the more sober-minded women of the tribe deplored ... It was more dignified, they decided to ignore her, to pretend that she was doing no more than most women did - making a lullaby or some such trifle - but in their hearts they could not help knowing that there was more to it than that. Why, they asked each other irritably, should she

18 See for example praise for the new cook Reg Hollow who not only makes nice hors d'oeuvres but also contributes songs. Frederick D. McCarthy, 'Diary 5: Yirrkala Diary No. 2 and Oenpelli' Papers of Frederick David McCarthy, MS 3513/14/5, AIATSIS, Canberra, 24 August 1948.

19 W. E. Harney, North of $23^{\circ}$ (Sydney: Australasian Publishing, 1947), $38,79$. 
want to make new songs at all? Were there not already innumerable tales for children, hallowed by centuries of use? Were there not lullabies that had been sung to their grandfathers and their great-grandfathers? What other songs should a woman need? ${ }^{20}$

We might reflect on the reasons these female commentators viewed the making of songs as indicative of personal empowerment in Aboriginal women. Just as anthropological history has pointed out the tendency of European colonists to ascribe the vices and traits of their own cultures to the studied other, ${ }^{21}$ both Margaret McArthur's diary and Dark's novel transcribed the cultural significance of women writing music in their own culture onto Indigenous contexts. In the 1940s, few women were recognised as significant composers in Australia or in the European tradition from which non-Indigenous Australian musical culture was derived. The depiction of women who composed as transgressive is a persistent theme in Western music history and one which McArthur and Dark mapped on to the Aboriginal cultures about which they were writing. ${ }^{22}$

Katharine Susannah Prichard's 1925 Coonardoo is another novel in which the singing and dancing of Aboriginal people was used to evoke nobility and ongoing wellbeing: ${ }^{23}$

And how Coonardoo sang for the fire corroboree! When Warieda gave the rhythm and air of the song, in a low melodious alto, clicking his kylies and the women began to sing, Coonardoo's voice quivered with her excitement, stretched shriller and higher to the strange magic words, and fell, creaking, whispering when Chitali came from the screen of bushes behind which the men were hiding. ${ }^{24}$

At the same time, this evocation of shrillness and creaking was unsettling to the non-Indigenous characters in the book.

20 Eleanor Dark, The Timeless Land (Melbourne: Fontana Books, 1980), 41.

21 See Victor Gordon Kiernan, Imperialism and Its Contradictions (New York: Routledge, 1995), 159: 'It has been noticed how ready the white man often is to invest the black man with all the worst impulses he is conscious of in himself.' See also Mick Gidley, ed., Representing Others: White views of Indigenous peoples (Exeter: University of Exeter Press, 1994). 3; Henrika Kuklick, The Savage Within: The social history of British anthropology, 1885-1945 (Cambridge: Cambridge University Press, 1991), 1, 279-80; Nicholas Thomas, Colonialism's Culture: Anthropology, travel and government (Melbourne: Melbourne University Press, 1994), 6-7.

22 See Amanda Harris, 'The Spectacle of Woman as Creator: Representation of women composers in the French, German and English feminist press 1880-1930', Women's History Review 23:1 (2014): 18-42.

23 Prichard also wrote in the preface to her play Brumby Innes that the corroboree as a device in the narrative was designed to 'give something of the dignity, beauty and mystery of a primitive people under the condition of a vanquished race'. Quoted in J. J. Healy, Literature and the Aborigine in Australia (St Lucia: University of Queensland Press, 1989), 144.

24 Katharine Susannah Prichard, Coonardoo, Introduction by Druisilla Modjeska (Sydney: Angus \& Robertson, 1994), 20. The use of descriptors such as 'shrill' and 'creaking' is consistent with Diane Collins' observation that Europeans described the music of 'savages' in terms evoking aural primitiveness, linking this to a cultural barbarity that negated any moral claim to the land. Collins, 'Acoustic Journeys': 11. 
On the hottest days of summer, under bare, pale-blue skies, drifts of the men's singing came to her from grey smoke-misted thickets below red bar peaks of the ridge ... Whenever she heard those chants, and the murmurous boom of a coolardie, Mrs Bessie knew what was happening. Old men of the tribes away from the camp were preparing youths, by crude rites of circumcision and mutilation, for the standing of men in the camp ... She was always restless and irritable while that singing was going on, more particularly if one of her own boys [young Aboriginal men who worked for her] was with the men. ${ }^{25}$

For Mrs Bessie, the agency and power evoked by participation in ceremony and corroboree threatened the control she may be able to exercise over her Aboriginal workers and unsettled her place as head of the station. Prichard's novel opened and closed with the musical theme that acted as a motif for the eponymous character. Prichard set up the book's soundscape from the opening sentence where Coonardoo was depicted singing and clicking two sticks together.

Over and over again, in a thin reedy voice, away at the back of her head, the melody flowed like water running over smooth pebbles in a dry creek bed. Winding and falling, the words rattled together and flew eerily, as if she were whispering to herself ... It was no more than a twitter in the shadow of dark bushes near the veranda; a twitter with the clicking of small sticks. ${ }^{26}$

Coonardoo's song, quoted in these first paragraphs, returns throughout the novel, both in her own voice and in that of her lover and aggressor, Hugh, as he evokes her spirit after assaulting her. Much of the literary analysis of this novel has focused on the equation of Coonardoo with the land, and criticism has revolved around 'the idea that the white man's desire for the Aboriginal woman would, if honoured, place him in a proper spiritual relationship to the land' ${ }^{27}$ This equation is evident in the opening passage in which Coonardoo's singing not only emerges from the sounds of the environment, but is described through evocations of pebbles, creek beds and shadows.

\footnotetext{
25 Prichard, Coonardoo, 23-4.

26 Prichard, Coonardoo, 1.

27 Susan Sheridan, quoted in Kerryn Goldsworthy, 'Fiction from 1900 to 1970', in The Cambridge Companion to Australian Literature, ed. Elizabeth Webby (Cambridge: Cambridge University Press, 2000), 123; see also Drusilla Modjeska's introduction to Prichard, Coonardoo, ix. For broader discussions of the conflation of Aboriginal people and land, see Bernard Smith, The Spectre of Truganini (Sydney: Australian Broadcasting Commission, 1980), 21; Collins, 'Acoustic Journeys': 12; Ann Curthoys, 'Expulsion, Exodus and Exile in White Australian Historical Mythology', Journal of Australian Studies 23:61 (1999): 13; David Symons, 'Words and Music: Clive Douglas and the Jindyworobak Manifesto', in The Soundscapes of Australia: Music, place and spirituality, ed. Fiona Richards (Aldershot: Ashgate, 2007), 98; and for the land conflated with woman see Kay Schaffer, Women and the Bush: Forces of desire in the Australian cultural tradition (Cambridge: Cambridge University Press, 1988), 62.
} 
Mary Durack's Keep Him My Country, published in 1955, also opened and closed with a description of the protagonist Stan Rolt's soundscape. The wafting strains of Aboriginal singing, didjeridu and clapsticks were used to symbolise relationship to, alienation from, and reconciliation with the land and its Indigenous inhabitants. The novel opens with:

Rolt stood for a moment, listening to the broken phrases of a familiar chant that trailed thinly on the morning air.

It was no more to him now than a song to fade on the wind like the smoke of a dying fire, though once he had believed in its power to hold and to possess. ${ }^{28}$

It ends with:

Behind them lament for the dead rose on a shivering thread of sound, shattered and broke into a falling cadence of grief, throbbing on through the bush like the pulse beat of her people, desolate, enduring. ${ }^{29}$

As these two excerpts suggest, for Stan Rolt, song drifting through his soundscape symbolised the love he was unable to pursue and the life force of Dalgerie, the Aboriginal woman with whom he had formed a relationship and who was now lost to him. Durack thus established from the outset the role of song in the narrative of Rolt's experience in the bush.

However, music played a more complex role in the novel than the leitmotif use for signifying Stan and Dalgerie. Just as John Bray contrasted the calls of Aboriginal singers with sounds of piano playing over the short-wave radio on the Arnhem Land Expedition, Durack used music as a trope for delineating difference between the races depicted in the narrative. The arrival of Stan's Uncle Arthur from the city prompted a shift in Durack's portrayals of music from the Aboriginal camps. Arthur's initial impressions of the music were unsettling, and his account apparently equated the 'lurking horrors' of insects and reptiles with the 'shrill', 'eerie' and 'savage' sounds that reach his ears:

Arthur retired early, hoping to escape further torture [from mosquitoes] under his net. He tested the unyielding greenhide bunk, played a torch around for lurking horrors and brushed away a goggling toad. A hollow sound like the distant rumble of thunder came from down the river. There was a shrill peal of laughter and a sharp rhythmic tapping of sticks and then the chant began, softly at first, rising to a crescendo like

28 Mary Durack, Keep Him My Country (Adelaide: Seal Books, 1973), 7.

29 Durack, Keep Him My Country, 349. 
the hurricane wind of the afternoon until the night was filled with eerie, savage sound, pulsating, deliberate. A fire blazed up on the high bank and black figures, painted like skeletons, stamped, leapt and postured.

"Savages," Arthur murmured, easing himself to a sitting posture on his comfortless bunk. "Surely he's going to tell them to stop? I can't be the only one wants to sleep."

But the revelry continued, uninterrupted and on a rising pitch of frenzy, into the early morning hours. ${ }^{30}$

As the days went on, Arthur began to experience the music not only as eerie and savage but as a collection of sounds directly in conflict with the sounds of his own world, and which created a cacophonous soundscape:

Seated on the exposed verandah he viewed the situation through dark glasses. Never in the heart of the city had he been aware of so much discordant sound. The strident tones of a gramophone mingled crazily with the almost incessant wild rhythm of corroboree. Birds in tens of thousands clustered on the trees, pecked about for insects in the mud, and shrieking like lost souls circled the house in dense clouds. Frogs croaked continuously in every key and thunder rolled like artillery in mountains of massed cloud. ${ }^{31}$

In Arthur's soundscape it was not the contrast of Aboriginal music with the 'strident' familiar music of the gramophone, but the combination of these with the shrieking and war-like noise of birds, frogs and thunder which unsettled him. The corroboree was thus depicted as an implicit and inseparable part of the cacophonous soundscape of the bush in which Aboriginal people as the composers and performers of the music he heard faded into a montage of land and animals.

Arthur's account also reveals the extent to which the industrial noise of the city, through its familiarity, stood for order. Durack's writing represents sentiments reminiscent of early colonial reactions to the organising of industry in Australia and the contrast of these with the uncomprehended and untamed sounds of Aboriginal people and the bush environment. As Diane Collins has shown, many early explorers 'listened with the same economic ear that heard in the industrial cacophony of nineteenth-century England profit's sweet sounds'. Collins notes that it was the sounds of industrious labour that resonated with these early travellers, far from home, not those of the unfamiliar environs of their travels:

30 Durack, Keep Him My Country, 313.

31 Durack, Keep Him My Country, 314. 
When Charles Sturt arrived in Australia the first acoustic he recorded was not the kookaburra but the sound of improvement. With intense satisfaction he heard, on Sydney's hills, that the "lowing of herds had succeeded the wild whoop of the savage; and the stillness of that once desert shore is now broken by the sound of the bugle and the busy hum of commerce". ${ }^{32}$

In Xavier Herbert's 1938 Capricornia too, the sound of the landscape was closely linked with Aboriginal music production. Music does not feature heavily as a trope in Capricornia, but one significant moment where it is used as a device is the scene in which the protagonist Norman realises his Aboriginality. Having been raised by an uncle to believe that his heritage was Indonesian, Norman's epiphany comes as he finds himself at night in the bush: 'Never before had night found him out of earshot of his kind [the non-Indigenous family who raised him]', and in the form of a song which rose up within him in response to the clicking sound of a golden beetle. As he began to beat in time with the insect's song, his own melody emerged from his chest until he broke the spell with an angry return to consciousness and refusal to identify with what was depicted in the novel as an innate Aboriginality driven by instinct, in spite of his rational self: 'He had to restrain himself from seeking relief in the Song of the Golden Beetle. Then for the first time he realised his Aboriginal heritage.' ${ }^{33}$

The fact that this description of singing and playing was used at a moment so central to the plot of the novel is significant to non-Indigenous conceptions of Aboriginal music. In Norman's experience, the urge to sing and play rhythms was constructed as instinctual and innate, something rising up from a deep indigeneity, revealing Norman's true nature. Here, in Herbert's rendition of Aboriginal instinct, music emerges from the body and ancestry of the people. This stands in contrast to the songs of white travellers which were composed, written and performed as deliberate music-making, and in some cases as attempts to counteract the wild uncontrollable sounds and activities of the land. In this interpretation of Aboriginal music, the agency of individuals who compose and perform is absent, and music-making is understood as native instinct.

The characterisation of Aboriginal music making as involuntary and primal was also a device used in Eleanor Dark's 1941 novel, The Timeless Land. In Dark's use of this trope, it functioned as a bridge between cultures for escaped convict, Andrew Prentice, when he distanced himself from his life of suffering as a member of the European underclass and prisoner, and embraced his new life

32 Collins, 'Acoustic Journeys': 11.

33 Xavier Herbert, Capricornia (Sydney: A \& R Classics, 2002), 334-5. See discussion of this passage also in Healy, Literature and the Aborigine in Australia, 163. 
in the bush and his union with an Aboriginal woman, Cunnembeillee. When Prentice attended an initiation ceremony to which he had been invited by his wife's tribe:

He found himself beating, as his companions were doing, upon his thighs and buttocks, but he did not stop. He was under some compulsion which he no longer wanted to resist. The glare brightened so that he blinked his dazzled eyes, and the tempo quickened, and his hands beat faster and his pulses with them ... the civilisation which had used him so ill fell away like an unfastened garment, and his body taught him what his mind would never grasp. ${ }^{34}$

In this use of Aboriginal music, Dark depicts the surrender of the white body to the compulsions of Indigenous Country and culture.

Adam Shoemaker has argued that considering only those novels still regarded today to be of literary importance does not give a holistic picture of the wider impact of mid-century writing by non-Indigenous authors portraying Aboriginal people. As Shoemaker has pointed out, Ion L. Idriess' fifty-five novels, selling a total of three million copies, offer a different perspective to those of Herbert and Prichard on Aboriginal people. ${ }^{35}$ The promotional blurb preceding the title page of Idriess' 1933 novel, Drums of Mer, indicates the extent to which his books were marketed as instructive of authentic Aboriginal life:

A vivid authentic picture of life among the headhunting warriors of the Torres Strait islands. Brought up native-fashion, a white man and two lovely white girls find themselves drawn together by their common desire to escape from primitive savagery to civilized life. ${ }^{36}$

As indicated by this blurb, Idriess' novels not only claimed to portray an authentic version of Aboriginal culture, but explicitly contrasted the "primitive savagery' of that culture to the far more desirable 'civilized life'. While the caricatured Aboriginal players in Idriess' novels engaged constantly in ceremonial practices which involved brutal killings and unrestrained wildness, their music was not described in any detail, but was portrayed as part of the frenzy of savage behaviour, so incomprehensible to the white refugees from civilisation. Indeed, in Drums of Mer, the protagonist, Jakara clearly articulated that lack of comprehension of Indigenous music was a pre-requisite for a proper and correct kind of whiteness. In his interactions with a white woman known as Eyes of the Sea, who had been raised to be part of a neighbouring Indigenous

34 Dark, The Timeless Land, 437-8.

35 Adam Shoemaker, Black Words White Page: Aboriginal literature 1929-1988 (St Lucia: University of Queensland Press, 1989), 54.

36 Ion L. Idriess, Drums of Mer (Sydney: Pacific Books, 1962). 
tribe, Jakara reprimanded her as a 'little white savage' for her appreciation of and absorption in the music of the culture to which she had been raised. Reproaching her for singing, Jakara explained why he disliked her involvement in the music of her tribe:

A girl of the white people should not sing at the sight of savages bound for murder and things more terrible ... can't you realize that you belong to another race? ... Don't you understand that we must cling to the ideals of our own people?"37

In Idriess' framing of whiteness, an appreciation of Aboriginal music was antithetical to a civilised and proper white life; the ability to comprehend, practice and embrace Indigenous musical culture was an indication of improper behaviour of the white race.

\section{The Music}

I began this chapter by suggesting that auditory sources have much to offer history writing, and yet, so far I have discussed only written accounts of auditory encounters. Compositions drawing on recordings of Aboriginal song offer one source of sonic expressions of the understanding and integration of Aboriginal music into non-Indigenous framings of culture. Peter Sculthorpe, perhaps Australia's best-known non-Indigenous composer, has been credited with the cultivation of an Australian national style of Western art music, chiefly through his use of melodies derived from Aboriginal song and the imitation of the sounds of the Australian bush (particularly birds) in his compositions. His earliest work to directly quote an Aboriginal melody was a film score from 1974, later adapted into a free-standing composition for string ensemble, Port Essington (1977). Linda Kouvaras describes Port Essington as portraying the collision between would-be settlers and inhospitable land'. ${ }^{38}$ As Kouvaras explains, in order to programmatically depict this collision, Sculthorpe used as his chief melodic material, the Djilile (whistling duck) melody derived from a recording made by A. P. Elkin in Arnhem Land in 1949. ${ }^{39}$

\footnotetext{
37 Idriess, Drums of Mer, 59.

38 Linda Kouvaras, 'From Port Essington to the Himalayas: Music, place and spirituality in two contemporary Australian compositions', in The Soundscapes of Australia: Music, place and spirituality, ed. Fiona Richards (Aldershot: Ashgate, 2007), 230.

39 The melody, part of Maraian ceremonies in central Arnhem Land, was called djilili and recorded by Elkin at Mainoru in 1949, although Sculthorpe repeatedly later stated that it was djilile recorded in the late 1950s. This spelling is corrected by Michael Hannan who transcribed the melody used by Sculthorpe. Michael Hannan 'Scoring Essington: Composition, comprovisation, collaboration', Screen Sound 2 (2011): 51; A. P. Elkin, 'Arnhem Land Music (Part 3)', Oceania 25:4 (1955): 331; A. P. Elkin, 'Maraian at Mainoru, 1949: I. Description', Oceania 31:4 (1961): 284.
} 
Although Sculthorpe's depiction originates in a period several decades after the Arnhem Land Expedition, the recording which inspired it was made by Elkin just one year after the expedition's conclusion, in an area of central Arnhem Land a couple of hundred kilometres inland from their first stop on Groote Eylandt. Elkin positioned himself in opposition to the work of the expedition, largely because of his disdain for the amateur status of its leader, C. P. Mountford. Martin Thomas has suggested that Elkin's expedition to central Arnhem Land in 1949 was in part an act designed to corner his own segment of the market for ethnographic knowledge about Aboriginal culture, and that this trip was at odds with his usual methods of sustained stays in the communities he studied. ${ }^{40}$ Controversy has plagued the modern uses of Elkin's recordings and discussion about issues of ethics and appropriation in Sculthorpe's use of the Djilile melody has been, if not extensive, then at least frequently recurring throughout musicological literature and popular discussions of Sculthorpe's compositional methodology. Perhaps the most rigorous of these is given by Stephen Knopoff, who compares Sculthorpe's rendering of the melody with the original recordings made by Elkin and finds that Sculthorpe's Djilile melody only approximately resembles the one originally sung by Kandamura, his brother, and a third man in the Djambarrpuyngu language. ${ }^{41}$

Nevertheless, Sculthorpe used his rendering of the melody, transcribed by his research assistant, Michael Hannan, in many forms over his compositional career, each time citing Elkin's recording as the origin of the melody he claimed to quote directly. ${ }^{42}$ In Port Essington, the transcribed melody is used throughout the work's six movements, though it is transformed in a number of ways. In the sections played by string orchestra, representing the land, the melody is clearly recognisable, while in the string trio, representing European settlement, it is more opaque. In Kouvaras' discussion of this compositional technique, and in Sculthorpe's own framing of the conflict between Europeans and the Australian landscape, Aboriginal music in the form of this single melody, comes to stand for land. This conflation of land and Aboriginal people was a frequent theme of Sculthorpe's discussions of the inspiration drawn from the Australian soundscape. Similarly, David Symons' analysis of other composers, such as Clive Douglas, who drew on Aboriginal music, suggests that they

see, as an essential vehicle for this Australian identification, the link with the Australian landscape via the evocation of Aboriginal culture. Further, it was not so much Aboriginal human culture which was a focus for either writers or composers, but rather an appreciation of its

\footnotetext{
40 Thomas, this volume; Martin Thomas, 'Expedition as Time Capsule: Introducing the American-Australian Scientific Expedition to Arnhem Land', in Exploring the Legacy of the 1948 Arnhem Land Expedition, eds M. Thomas and M. Neale (Canberra: ANU E Press, 2011), 8.

41 Steven Knopoff, 'Cross-Cultural Appropriation: A musicologist's perspective', Sounds Australian 67 (2006): 25-6.

42 Hannan, 'Scoring Essington', 51.
} 
mystic link with the land and the Dreamtime which was seen as a way of (in Douglas' words) forging a link "which will serve to connect the composer's thought to the land itself". ${ }^{43}$

In Sculthorpe's framing of his work, the bush was represented in music composed in 'my own manner' (or by Kouvaras in 'Sculthorpe's own style'). ${ }^{44}$ It is not entirely clear what constituted this style, except that the music for string orchestra to which Sculthorpe referred is transparently based on the transcription of the Arnhem Land melody and rhythm, whereas in the string trio this melody is camouflaged in a harmonic style evocative of eighteenth century European string writing. This string trio setting drew its material from the Djilile melody as well, and thus Sculthorpe would seem to be commenting on European attempts to civilise the raw material of the Australian bush (conflated here with Aboriginal people and their arts) by altering its essential elements into an unrecognisable form.

As Sculthorpe's introduction to the piece made explicit, the work programmatically depicts the European attempt to create an ongoing settlement at Port Essington, an attempt which failed on two occasions in the course of the nineteenth century. ${ }^{45}$ In his description: 'those living there were unable to adapt to the peculiar conditions of the land'. ${ }^{46}$ In Sculthorpe's musical rendering of the events, this adaptation also failed, as 'the insistence of the music of the string orchestra [the bush] brings about a withdrawal of the music played by the string trio [the Europeans]'. In musical terms, this withdrawal is characterised in the second movement by the increasingly frequent interjection of dissonant chords from the string orchestra, which unsettle the structured harmonic progressions of the string trio (Figure 1). These interjections become more and more persistent, destabilising the coherence of the string trio's harmony. As Sculthorpe intimates, the failure of the European colony at Port Essington seems to have been mainly due to the difficulty of coping with the tropical environment, in particular with outbreaks of malaria and the unfamiliarity of the climate for the purposes of agriculture. In historical accounts of the settlement from 1838 to 1849 , a non-confrontational approach in regard to Aborigines was taken by the Europeans, and the settlement may have been regularly supplied by Aboriginal people with seafood and plant foodstuffs from the surrounding Country. ${ }^{47}$ And yet, in his work Port Essington, Sculthorpe presents this as an oppositional breakdown with the Europeans, represented by chamber music, versus the bush, represented by an Aboriginal melody.

\footnotetext{
43 Symons, 'Words and Music', 98.

44 Peter Sculthorpe, Port Essington for Strings (London: Faber Music, 1980), prologue; Kouvaras, 'From Port Essington', 232.

45 Port Essington was also the endpoint for Ludwig Leichhardt's first exploratory expedition; after being presumed lost, Leichhardt arrived at the settlement in December 1845. Sculthorpe mentions Leichhardt's Expedition in the Prologue to the work. His expeditions were subsequently the inspiration for Patrick White's 1957 novel Voss, which contains only very brief descriptions of Aboriginal people singing as the expedition group suffers and struggles through the foreign landscape. Patrick White, Voss (Harmondsworth \& Ringwood: Penguin, 1960).

46 Sculthorpe, Port Essington for Strings, prologue.

47 Jim Allen, Port Essington: The historical archaeology of a north Australian nineteenth-century military outpost (Sydney: Sydney University Press, 2008), 128.
} 

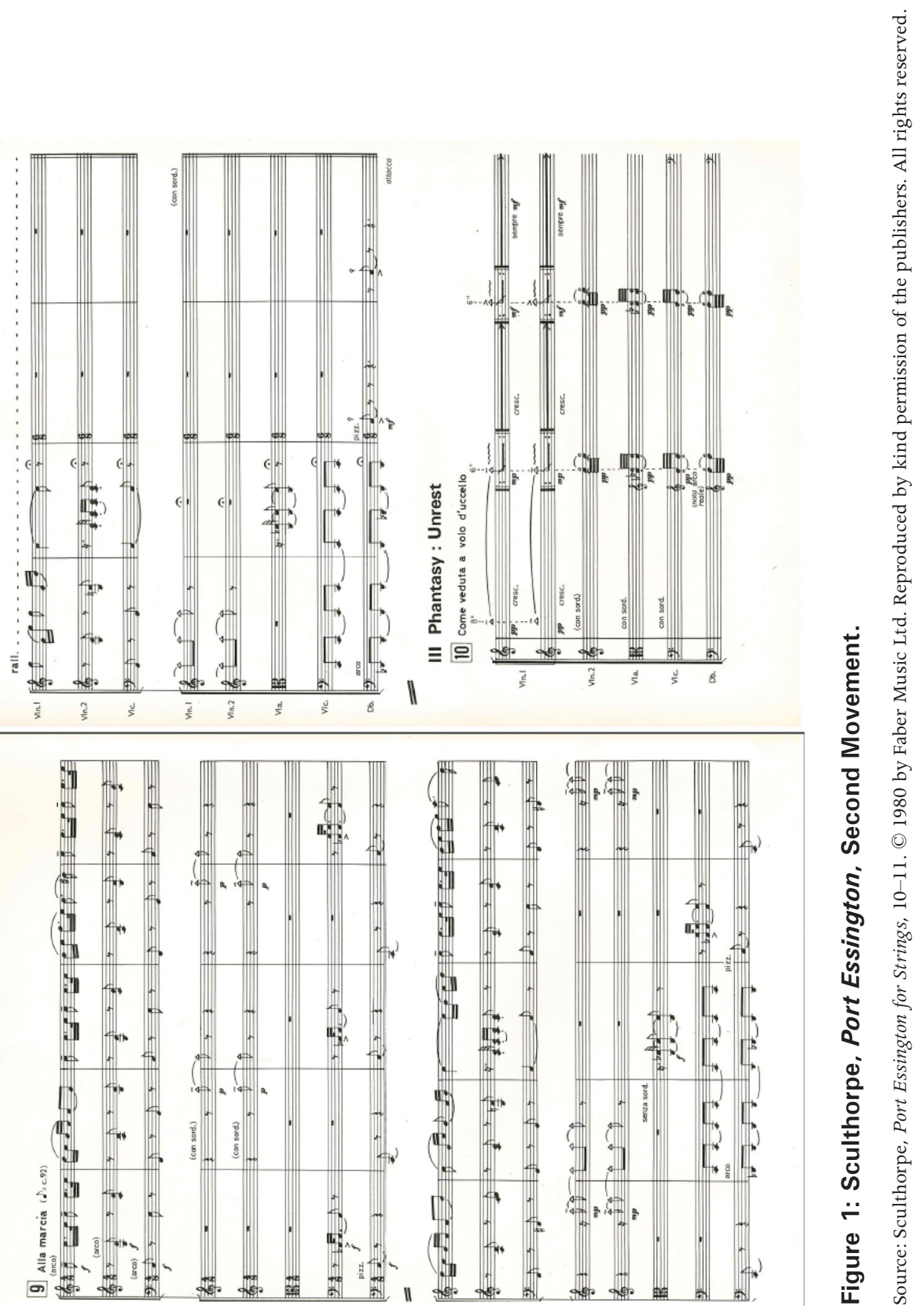


\section{Hearing Aboriginal Music Making in Non-Indigenous Accounts of the Bush from the Mid-Twentieth Century}

Following this is a movement for the string orchestra in which all instruments use specialised string techniques to imitate bird sounds from the Australian bush. When the string trio returns, the Djilile melody is now transparent, though rhythmically altered, in the cello line throughout the movement, but is again harmonised by diatonic progressions in the remaining two parts of the trio. This harmony is unable to be sustained for the entire movement, and the string orchestra again appears, imposing the Djilile melody in its original rhythmic setting and creating bitonal clashes with the consonance of the trio (Figure 2).
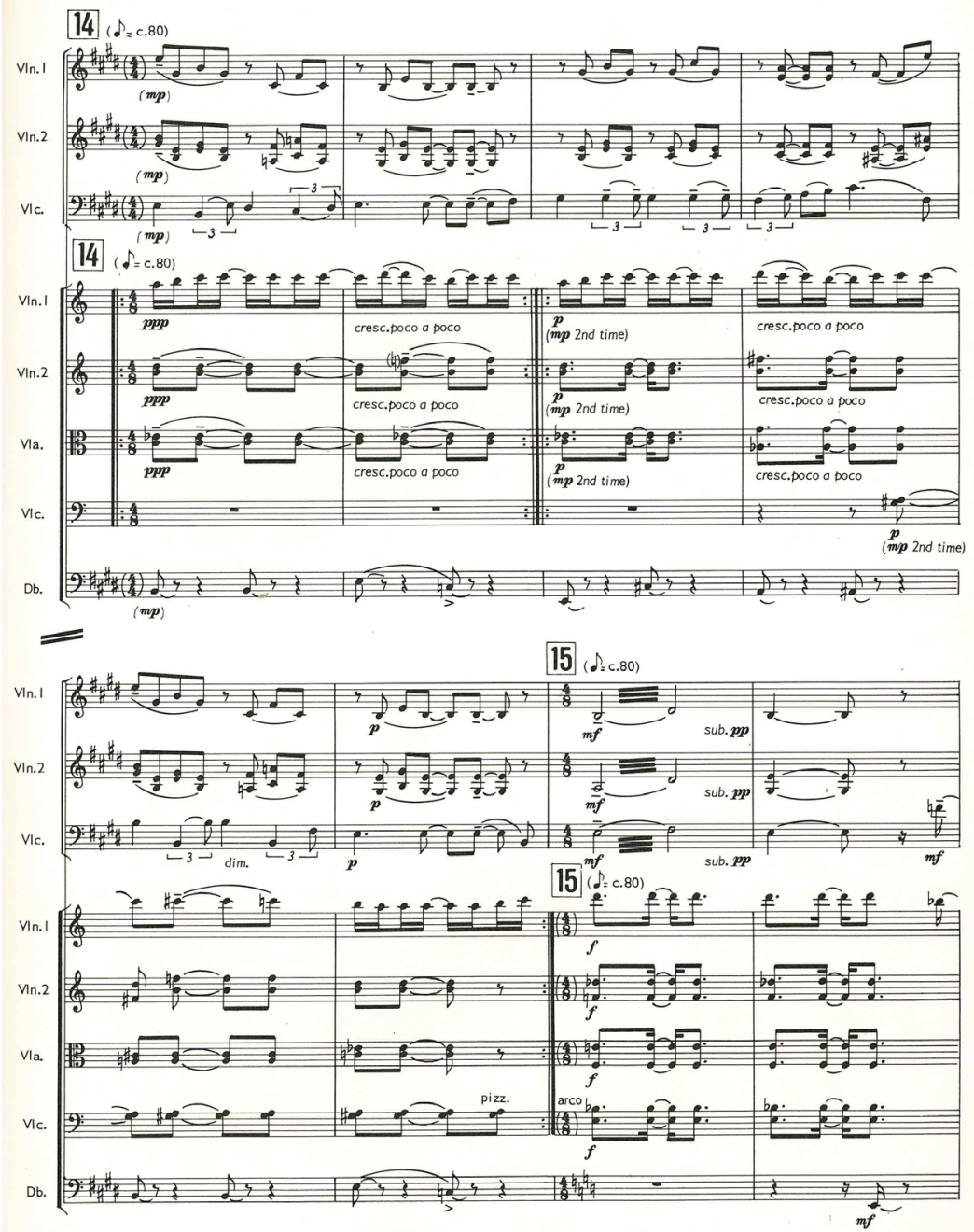

Figure 2: Sculthorpe, Port Essington, Fourth Movement.

Source: Sculthorpe, Port Essington for Strings, 15. (C) 1980 by Faber Music Ltd. Reproduced by kind permission of the publishers. All rights reserved. 
Sculthorpe described the music of the fifth movement as that of the Europeans withdrawing, following which, 'the music is echoed by the string orchestra, suggesting that some kind of agreement could have been possible' ${ }^{48}$ We can only speculate on how Sculthorpe himself may have conceptualised such an agreement, given that, at this point in the music, the Diilile theme has been transformed into such a statement of European classical music as to be barely recognisable as a melody derived from the original transcription (Figure 3). This absorption of the melody implies that the agreement could only have been reached through the assimilation of Arnhem Land into European traditions. This reading of cultural assimilation is justified, I argue, by the very literal programmatic framework in which Sculthorpe inscribes the meaning of the Aboriginal melody in his notes about the piece, published alongside the musical score.

Knopoff suggests that Sculthorpe's positing of an Aboriginal origin to a nonAboriginal culture raises issues of representation that are quite separate to any discussion of appropriation: 'some critics and listeners have conflated issues of appropriation (in this case, taking a melody from one context for use in another) with what are actually issues of representation (positing an Aboriginal origin to a melody in a non-Aboriginal composition).' Knopoff implies, but not does not exactly make explicit, the connotations of Sculthorpe's representation of his compositions as based on Aboriginal music. ${ }^{49}$ Indeed, it may be possible to conceive of Sculthorpe's frequent reiteration that his works (from Essington, through Djilile, to Kakadu) were based on an authentic Arnhem Land melody, as appropriation of a different kind; that by co-opting the exoticism and prestige derived from drawing on Australian Indigenous culture, Sculthorpe appropriated the rhetorical capital of Aboriginal culture without being attentive to its cultural context, or even without being true to the melodic and rhythmic content of the original musical object. Sculthorpe thereby lay claim to a national style drawing on the materials of the very land of Australia itself, through its Indigenous people.

48 Sculthorpe, Port Essington for Strings, prologue.

49 Knopoff does state that although works such as Kakadu have attracted interest because of their ostensible reference to Aboriginal song, no direct benefit of this success has flowed back to the communities whose music inspired the work. Knopoff, 'Cross-Cultural Appropriation', 26-7. 

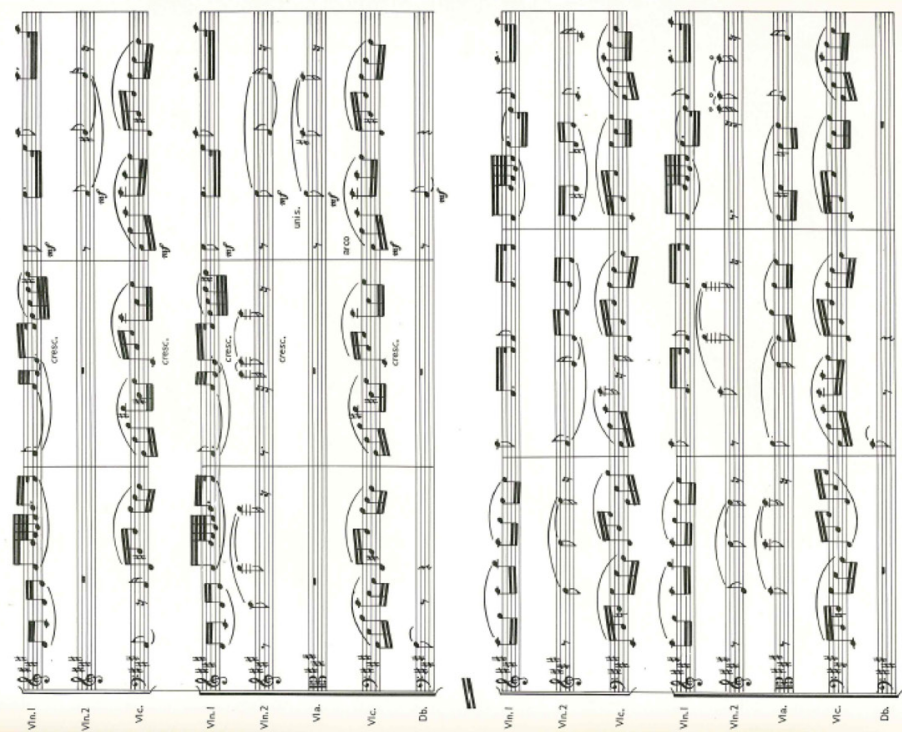

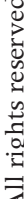
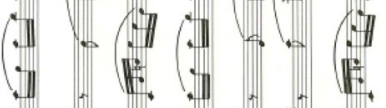

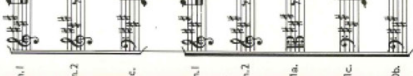

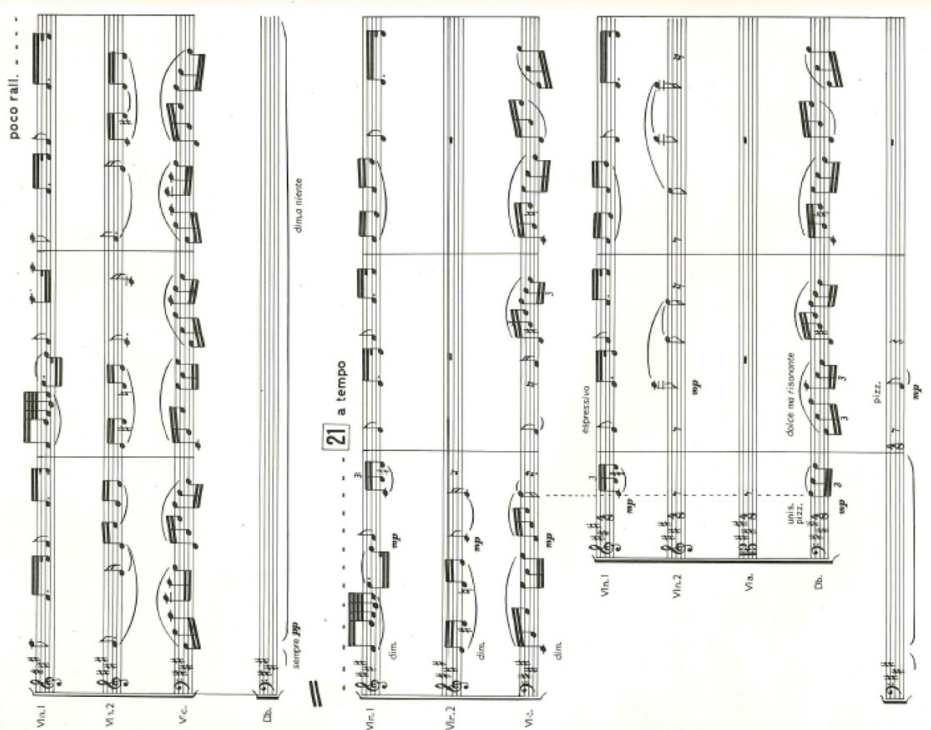




\section{Conclusion}

The ways in which Indigenous music has been portrayed by non-Indigenous diarists, novelists and composers reflects broader attitudes towards Indigenous people and culture in the mid-century. As we have seen from diaries, novels and music, limited possibilities were available for Indigenous auditory culture to play a role in non-Indigenous narratives, whether as first-person accounts of heard experience or as fictional portraits of Aboriginal culture. Certain tropes recur with regularity: the contrast of the ordered and familiar sounds of European music with the chaotic, wild and cacophonous sounds of Aboriginal music and the bush soundscape; the conflation of the sounds produced in the musical traditions and practices of Aboriginal people with the organic sounds of animals, weather and the landscape; notions of primal instinct, innateness and compulsion which accompanied ideas about Aboriginal music production; and the association of the practice of music with empowerment and continuation of tradition. There are many parallels here with Ann Curthoys' survey of Australian history-writing in the same period. Curthoys writes about settlement narratives in which Aboriginal people barely appear, or at least not in mutli-dimensional ways:

The literary critic Peter Otto suggests that the popular narrative of horror in the desert, of the land and landscape as the malignant unknown, is not innocent, or transparent. Rather, it offers a colonial society a way of displacing the conflict between settlers and indigenous peoples onto a more acceptable narrative of a direct conflict between the settler and the land itself. The land and the indigenous people become merged, the former foregrounded, the latter denied a place in history at all. ${ }^{50}$

The narratives I have discussed confined understanding of Aboriginal music to limiting paradigms and always in reference to non-Indigenous culture, rather than seeking to frame Indigenous music within its own cultural references. Indigenous music in these accounts is heard as a projection of the listeners' own cultural experience of the bush or the Australian soundscape, notwithstanding the framing of these experiences in terms of cultural authenticity (in particular by Sculthorpe and Idriess). Most frequently these hearings were projections of the authors' own feelings of isolation, alienation, or exoticised attraction to their surroundings rather than any kind of true representation of an other, or a foreign auditory culture. ${ }^{51}$ In this sense, what we can hear through an analysis

50 Curthoys, 'Expulsion, Exodus and Exile in White Australian Historical Mythology', 13.

51 See Gidley's discussion (following Edward Said) of non-Indigenous writers being able only to depict elements of themselves in their representation of the other. Gidley, ed., Representing Others, 3; and Bernard Smith on the 'guilty colonial hearts that sought to stifle the story of despair, projecting their fear and guilt upon nature itself'. Smith, The Spectre of Truganini, 21. 
4. Hearing Aboriginal Music Making in Non-Indigenous Accounts of the Bush from the Mid-Twentieth Century

of these written and musical texts is the sound of non-Indigenous Australians grappling with their own dislocation in the country in which they were born, and the heightened awareness of this cultural displacement through hearings of Indigenous music.

\section{Acknowledgements}

This chapter has benefitted from comments on an early draft from members of the Musicology Colloquium Series at the Sydney Conservatorium of Music, especially from Linda Barwick, as well as from the insights of two anonymous reviewers.

\section{References}

Allen, Jim. Port Essington: The historical archaeology of a north Australian nineteenth-century military outpost (Sydney: Sydney University Press, 2008).

Blacking, John. How Musical Is Man? (Seattle: University of Washington Press, 1973).

Collins, Diane. Acoustic Journeys: Exploration and the search for an aural history of Australia', Australian Historical Studies 37:128 (2006): 1-17.

Curthoys, Ann. 'Expulsion, Exodus and Exile in White Australian Historical Mythology', Journal of Australian Studies 23:61 (1999): 1-19.

Damousi, Joy, and Desley Deacon, eds. Talking and Listening in the Age of Modernity: Essays on the history of sound (Canberra: ANU E Press, 2007).

Dark, Eleanor. The Timeless Land (Melbourne: Fontana Books, 1980).

Durack, Mary. Keep Him My Country (Adelaide: Seal Books, 1973).

Elkin, A. P. 'Arnhem Land Music (Part 3)', Oceania 25:4 (1955): 292-342.

Elkin, A. P. 'Maraian at Mainoru, 1949: I. Description', Oceania 31:4 (1961): 259-93.

Gidley, Mick, ed. Representing Others: White views of Indigenous peoples (Exeter: University of Exeter Press, 1994).

Goldsworthy, Kerryn. 'Fiction from 1900 to 1970', in The Cambridge Companion to Australian Literature, ed. Elizabeth Webby (Cambridge: Cambridge University Press, 2000), 105-33. 
Hannan, Michael. 'Scoring Essington: Composition, comprovisation, collaboration', Screen Sound 2 (2011): 48-63.

Harney, W. E. North of $23^{\circ}$ (Sydney: Australasian Publishing, 1947).

Harris, Amanda. 'Food, Feeding and Consumption (or the Cook, the Wife and the Nutritionist): The politics of gender and class in a 1948 Australian expedition', History and Anthropology 24:3 (2013): 1-17.

Harris, Amanda. 'The Spectacle of Woman as Creator: Representation of women composers in the French, German and English feminist press 1880-1930', Women's History Review 23:1 (2014): 18-42.

Healy, J. J. Literature and the Aborigine in Australia (St Lucia: University of Queensland Press, 1989).

Herbert, Xavier. Capricornia (Sydney: A \& R Classics, 2002).

Idriess, Ion L. Drums of Mer (Sydney: Pacific Books, 1962).

Kiernan, Victor Gordon. Imperialism and Its Contradictions (New York: Routledge, 1995).

Knopoff, Steven. 'Cross-Cultural Appropriation: A musicologist's perspective', Sounds Australian 67 (2006): 2-27.

Kouvaras, Linda. 'From Port Essington to the Himalayas: Music, place and spirituality in two contemporary Australian compositions', in The Soundscapes of Australia: Music, place and spirituality, ed. Fiona Richards (Aldershot: Ashgate, 2007), 229-45.

Kuklick, Henrika. The Savage Within: The social history of British anthropology, 1885-1945 (Cambridge: Cambridge University Press, 1991).

Picker, John M. Victorian Soundscapes (New York: Oxford University Press, 2003).

Prichard, Katharine Susannah. Coonardoo, Introduction by Drusilla Modjeska (Sydney: Angus \& Robertson, 1994).

Schafer, R. Murray. The Tuning of the World (New York: Knopf, 1977).

Schafer, R. Murray. 'Soundscapes and Earwitnesses', in Hearing History: A reader, ed. Mark M. Smith (Athens: University of Georgia Press, 2004), 3-9.

Schaffer, Kay. Women and the Bush: Forces of desire in the Australian cultural tradition (Cambridge: Cambridge University Press, 1988). 
4. Hearing Aboriginal Music Making in Non-Indigenous Accounts of the Bush from the Mid-Twentieth Century

Sculthorpe, Peter. Port Essington for Strings (London: Faber Music, 1980).

Shoemaker, Adam. Black Words White Page: Aboriginal literature 1929-1988 (St Lucia: University of Queensland Press, 1989).

Simpson, Colin. Adam in Ochre: Inside Aboriginal Australia (Sydney: Angus \& Robertson, 1962).

Smith, Bernard. The Spectre of Truganini (Sydney: Australian Broadcasting Commission, 1980).

Smith, Mark M., ed. Hearing History: A reader (Athens: University of Georgia Press, 2004).

Symons, David. 'Words and Music: Clive Douglas and the Jindyworobak Manifesto', in The Soundscapes of Australia: Music, place and spirituality, ed. Fiona Richards (Aldershot: Ashgate, 2007), 93-115.

Thomas, Martin. 'The Rush to Record: Transmitting the sound of Aboriginal culture', Journal of Australian Studies 31:90 (2007): 107-202.

Thomas, Martin. 'Expedition as Time Capsule: Introducing the AmericanAustralian Scientific Expedition to Arnhem Land', in Exploring the Legacy of the 1948 Arnhem Land Expedition, eds M. Thomas and M. Neale (Canberra: ANU E Press, 2011), 1-30.

Thomas, Nicholas. Colonialism's Culture: Anthropology, travel and government (Melbourne: Melbourne University Press, 1994).

Toner, Peter. 'Sing a Country of the Mind: The articulation of place in Dhalwangu Song', in The Soundscapes of Australia: Music, place and spirituality, ed. Fiona Richards (Aldershot: Ashgate, 2007), 165-83.

Weliver, Phyllis. 'Tom-Toms, Dream-Fugues and Poppy Juice: East meets west in nineteenth-century fiction', in Music and Orientalism in the British Empire, 1780s-1940s, eds Martin Clayton and Bennett Zon (Aldershot: Ashgate, 2007), 257-76.

White, Patrick. Voss (Harmondsworth \& Ringwood: Penguin, 1960).

Woodfield, Ian. English Musicians in the Age of Exploration (Stuyvesant: Pendragon Press, 1995). 
This text taken from Circulating Cultures: Exchanges of Australian Indigenous music, dance and media, edited by Amanda Harris, published 2014 by ANU Press, The Australian National University, Canberra, Australia. 